\title{
Measuring the effects of different factors influencing on the readiness of SMEs towards digitalization: A multiple perspectives design of decision support system
}

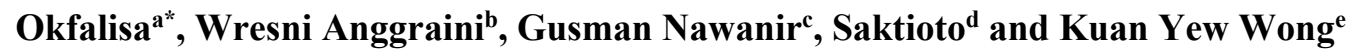

anformatics Engineering Department, Universitas Islam Negeri Sultan Syarif Kasim Riau, 28293 Pekanbaru, Riau, Indonesia

${ }^{b}$ Industrial Engineering Department, Universitas Islam Negeri Sultan Syarif Kasim, 28293 Pekanbaru, Riau, Indonesia

${ }^{c}$ Faculty of Industrial Management, Universiti Malaysia Pahang, 26300 Kuantan, Pahang, Malaysia

dPhysic Department, Universitas Riau, 28293 Pekanbaru, Riau, Indonesia

${ }^{e}$ Manufacturing and Industrial Engineering Department, Universiti Teknologi Malaysia, 81310 Johor Bahru, Johor, Malaysia. Malaysia

\begin{tabular}{l}
\hline C H R O N I C L E \\
\hline Article history: \\
Received October 28, 2020 \\
Received in revised format: \\
December 29, 2020 \\
Accepted January 42021 \\
Available online \\
January 4, 2021 \\
\hline Keywords: \\
Small-Medium Enterprises \\
Performance Measurement \\
Decision Support System \\
Digitalization Readiness \\
Fuzzy Analytical Hierarchy \\
Process
\end{tabular}

\begin{abstract}
A B S T R A C T
The development of small and medium enterprises (SMEs) becomes the benchmark and leading position for developing countries' economies. The digital transformation demands strategies, desires, and awareness of Information Technology (IT)-based market players and investments. Despite the transformation of a digital business platform, many SMEs have stumbled in the middle road. Therefore, this study aimed to determine priority indicators in assessing SMEs' readiness towards digitalization and evolving a readiness model for SMEs based on the Decision Support System (DSS) approach. Multiple stakeholders' viewpoints, particularly regarding academicians, governments, investors, market places, and SMEs' business actors as targeted respondents, were scrutinized quantitatively and qualitatively to verify the proposed factors. The priority weights of factors have been examined from economic and IT perspectives and derived through deploying the Fuzzy Analytical Hierarchy Process (F-AHP) method. This study reveals the rank of measures necessary to assess the readiness of the digital revolution of SMEs. Transaction preparedness in SMEs' cultural, educational, financial, and technological infrastructure views grows into the principal components during this assessment with 0.30 of vector value, accompanied by marketing and micro-environment at 0.24 , management at 0.20 , macro-environment at 0.03 and business activities at 0.02 , respectively. For the recommendation purposes, the rubric segmented SME fitness into three levels, low, middle, and high performance. The prototype system DSS-SMEsReadiness was then evolved in order to simplify the adoption of the DSS method in the SME performance measurement model. The software analysis demonstrates that this application would assist decision-makers to ascertain SMEs' readiness to digitalize. The future recommendation provides SMEs and stakeholders with knowledge transfers and acclimatization for taking the appropriate option about their business strategy, management resources, skills, and assistance programs for SMEs. This model attempts to reduce SME digitalization disruptions and achieve a digital business's growth and sustainability in a nutshell.
\end{abstract}

C 2021 by the authors; licensee Growing Science, Canada.

\section{Introduction}

The annual report 2018-2019 of the European Union indicates that SMEs' population reached 99.8\%, absorbed 66.6\% of the workers, and contributed $56.4 \%$ of the country's larger economies (Muller et al., 2019). The contribution of SMEs to labor access in ASEAN countries was 66.3 percent, and the gross added value was 42.2 percent (OECD / ERIA, 2018).

* Corresponding author.

E-mail address: okfalisa@gmail.com (Okfalisa)

C 2021 by the authors; licensee Growing Science, Canada.

doi: $10.5267 /$ j.dsl.2021.1.002 
However, Indonesia is gaining success outside other ASEAN countries such as Brunei, Singapore, Malaysia, and Thailand. The achievement notifies competitive and infrastructure classification Gross Domestic Product (GDP) (Schwab, 2016). Since the absorption of labor by small and medium-sized enterprises is elevated in Indonesia, productivity is low relative to its ASEAN partners, particularly Laos, Myanmar, and Cambodia.

When the monetary crisis hit Indonesia in 1998, small and medium-sized businesses were relative to large firms. Most SMEs do not rely very much on large capital or foreign lending in foreign currencies. The contribution of small and mediumsized businesses to GDP currently absorbs about $97 \%$ of the most workforce. Thus, it shows SMEs can boost their community standard of living, open new opportunities for jobs (Syafrida et al., 2018), assist larger companies (Berry et al., 2001), increase entrepreneurship during the financial crisis (Rinto et al., 2020; Amir et al., 2020), and encourage non-oil and gas companies (Berry et al., 2001). SMEs in Indonesia and other countries faced a range of challenges and issues relating to equity and human capital, competitiveness, commercial-system, innovation, bureaucracy, government readiness, market conceivable, creativity, export prospects, the resistance of the business owners and sustainability, local market awareness, women's empowerment, the internet and digital transformation, financial enrolment, productivity, commercializing, and infrastructure (Rahadi, 2016; Syamala \& Srinivasa, 2017; AlMaimani \& Johari, 2015). External and environmental issues and challenges are fantastic opportunities for developing small and medium-sized enterprises worldwide, especially in Indonesia.

Digital transformation encourages digital technology to become the primary requirement in business activities. The more updated utilization of Information Communication Technology (ICT) and the higher interconnectedness-role of the cyber world in wireless or mobile technology have immersed a very promising investment in facing the world business competition. Unfortunately, developed countries, such as the United Kingdom (UK), still lack initiative, desire, and knowledge related to ICT investment in the digital transformation process (Barnard. et al., 2017). Of course, this condition deteriorates in developing countries. The contribution of data-driven business in the digital world, such as the voice-overIP (VoIP), flexible work processes, digital marketing, online shopping, and the speed of internet connection, broke down to sign in the maximized benefits. The technology adoption grows into a SMEs consideration in developing investment strategies.

Digitalization has been proven effective in leveraging SMEs' business process activities (Liang et al., 2017). It reinforces the effectiveness of overall equipment in cross-industry up to $35 \%$, inventory reduction up to $60 \%$, labor productivity likely $25 \%$, logistic cost reduction acceptable $35 \%$, output improvement up to $40 \%$, and production time reduction up to $20 \%$ (Hoellthaler et al., 2018). The utilization of digital initiatives increased revenue gains by $26 \%$ and reaching $22 \%$ in cost savings.

SMEs' development in Indonesia is adapting to creative technology by introducing the online platform for product marketing in the current digital era. This awareness was demonstrated in the form of policies by the Ministry of Cooperatives and Small and Medium Enterprises (Kemenkop UKM) and the Ministry of Communication and Information Technology (Kemkominfo) together with e-commerce actors by initiating a program titled eight Million SMEs Go Online (Kominfo, 2020). Several marketplaces e-commerce sites in Indonesia, such as Lazada, Shopee, MatahariMall.com, BliBli.com, Bukalapak, Tokopedia, and Blanja.com who have successfully developed online businesses, were involved in the program. However, the results exhibit that SMEs' involvement is still limited. Moreover, many of the rising marketplaces that categorized as SMEs' digital business platforms were crumbled. The effervescence is due to the lack of awareness, understanding, and knowledge transfer effectiveness from the top to lower management. Besides, insufficient knowledge in using ICT in digitalizing, exploiting data, and information for marketing and supply chain activities (Rizk, 2004) triggered this program's un-optimal achievement.

The economic crisis in 2008 disrupted the countries' economy and finance, especially for large enterprises whose business is high reflects on the dollar exchange rate. However, SMEs mastering the retail products, the regional capital, and directly serving the customers could survive during this crisis. Nevertheless, the presence of the Covid-19 changed the structure of the world economy, which had a significant socio-economic impact on the development of SMEs worldwide (Nicola et al., 2020). The pandemics brought negative impacts, especially in tourism and leisure, aviation and maritime, automotive, construction and real estate, manufacturing, and financial services. However, the favorable implication directly or not is felt in various sectors, including agriculture, ICT, E-commerce, personal healthcare, food processing and retail, and medical supply and services. Thus, this condition encourages the transformation towards digitization to turn into an obligation to ensure SMEs' sustainability (Kuckertz et al., 2020). SMEs call for the paradigm exchanges to lead to digitalization by revitalizing strategy with flexible SMEs model development.

Sophie and Nadine (2019) classified several obstacles to SMEs' digitalization. First is technical barriers that disclose to the embracement of the internet of things (IoT), big data and analytics, cloud computing, cybersecurity, mixed and augmented reality, advanced manufacturing solutions, additive manufacturing, simulation of connected machines, and artificial intelligence, which were insufficiently used for working out the effectiveness and efficiencies of business activities and services (Paschou et al., 2018). Besides, the constraint of financial roots, technical resources, and infrastructure adoption 
turns into impossible to be executed (Mittal et al., 2018; Lerch et al., 2015). The second is organizational barriers. Digitalization affects the radical changes on critical business operations, products, processes, organizational structures, management concepts (Matt et al., 2015); new competencies, resources, and collaboration towards management innovation (Lerch et al., 2015); cultural shock (the unwillingness to change, the ignorance to changes, and underestimate) (Dubruc et al., 2014; Peillon et al., 2018). The third obstacle is human resource barriers that lead to competencies and skills towards utilizing digital technology, especially for the sales competencies or customer interfacing skills (Süße et al., 2018; Coreynen et al., 2017). Finally, the customers recite to the lack of control over information due to the security and privacy violation and the ambiguity of information and analysis from the customer activities (Klein et al., 2018).

Digital transformation increases and maximizes the SMEs' business performance. Considering that ICT investment in transformation takes a lot of effort and risks in financial, infrastructure, operational management, digital adoption, and digital and learning skills, the measurement of SMEs' readiness passes into one solution to avoid the various jeopardization of digital deterioration. Understanding the degree of SMEs' digitalization and servitization leads to the optimal digital solution and business strategy, business model, and technology adoption (Paschou et al., 2018). Thus, the possible obstacles both management and technology are initially anticipated in ensuring the SMEs' sustainability. Previous researchers perceived e-readiness from various views of divergent perspectives, context, people's background, and purposes (Lou \& Goulding, 2010). Thus, the emergence of e-readiness divergence between the notion and practical implication is ineluctable (Bridges.org, 2017). Beacon (Khalfan et al., 2001) and Verdict (Ruikar et al.,2006), as one of the organizational readiness tools, fizzled out to lead the organization improvements and suggested the priority concerns the success achievements. The General Practitioner Information System (GPIS) and New IT/IS Capability Evaluation (NICE) measurement model (Salah, 2003 ) is a tool that takes no notice of the stakeholders' involvement instead of hiring technology experts for a particular industry assessment. The Building Information Modelling (BIM) Maturity Matrix is an inflexible model and restricted for BIM organization. The maturity level index is born to complete the technology readiness levels. Nevertheless, this leveling index is far from the standard e-readiness tool for the SME industry (Lou, 2019). Lou et al. (2019) found e-readiness on the construction (ERiC) framework as a new alternative tool for measuring the organizational precaution degree to cover and propitious the digital economy. Unfortunately, this framework is distinctively designed for the United Kingdom (UK) Construction Industry (CI) and case studies.

Therefore, this study tries to assess SMEs' readiness towards digitalization by engaging the multiple perspectives outlook viz. economic and ICT perspectives from governments, investors, the marketplace, and SMEs industries. The enormous population, geographical region, cultural and social diversity, political country, and the circumspection of financial and technology infrastructures within developing countries such as Indonesia grow into a new challenge of this research novelty. Digitalization awareness, infrastructure, market networks, connections, data analytics, and business intelligence adoption (Rizk, 2004) are considered indicators embedded during the transaction, marketing, production, and management processes. Investors' appraisal regarding the sharing of economic, hazards, profit, and lost identification enriches the SMEs' model in analyzing the proposed suggestion and direction of new start-up platforms to increase effectiveness and efficiencies while fitting into Indonesia's current situation.

A Decision Support (DSS) prototype was employed as a business intelligence platform to simplify the assessment mechanism process. DSS sets the SMEs model through the calculation and weighted indicators measurement as criteria using F-AHP. Meanwhile, the alternatives are then proposed in consonance with the performance of rubric categories. DSS can assist the organizational management in analyzing and managing activities on the decision-making (Power, 2003). The utilization of DSS in various scientific fields in decision-making has been tested and verified with positive results, such as in the logistics area (Toni et al., 2020), customer relationship management (Saleem \& Al-Malaise, 2012; Fadiya et al., 2015), clinical information system (Francesco et al., 2020), enterprise resource planning (Bokovec et al., 2015), and supply chain management fields (Siluk et al., 2017). Referring to the measurement, DSS has been successfully predicted and assessed workforce behaviour in an organization (Enge et al., 2017). More importantly, Helversen et al. (2018) enhanced DSS's application in reviewing customer evaluation at online shopping by recommending the right online store based on customer needs.

In a nutshell, this study attempts to develop an SME model by identifying priority indicators in measuring SMEs' readiness towards digitalization. Hence, the DSS prototype system's design as an automatic tool for the SME model will be discussed.

\section{Materials and Methods}

\subsection{Conceptual Model Development}

Previous research treasured trove that the facing obstacles can distinguish the measurement of SMEs' readiness during the digitalization. The critical issues are found in technical and organizational barriers. The utilization of digital technology in business and supply chain activities from the top up to down floor (Sophie and Nadine, 2019; Paschou et al., 2018), financial support on technology adoption, technical infrastructure (Lerch et al., 2015), and resources (Mittal et al., 2018) grow into a primary concern of technical issues. Meanwhile, the organizational roadblocks describe in organizational structure, 
management concepts (Rauch et al., 2017), new competencies and skills on digitalization adoption (Süße et al., 2018 and Coreynen et al., 2017; Klein et al., 2018), collaboration and innovation (Lerch et al., 2015), cultural shock (Peillon et al., 2018). Several interviews with SME stakeholders from academicians, governments, marketplace actors, SME owners, and investors were attended to consolidate the findings. The interviews reveal the possible indicators and sub-indicators in measuring SMEs' readiness. How the variables act as a component of the SME model are detailed explained in this study. As a side of business economics, SMEs' readiness towards digitalization is measured by the following indicators.

\subsubsection{Business activities (BA)}

BA is defined as a series of SME's supply chain activities from the production to the desired results. The activities include selecting and managing strategy, resources, and services governing daily business activities (Medini \& Bourey, 2012; Umeh et al., 2020). For the measurement of SMEs' readiness, BA's main concerns are highlighted by production, distribution, and consumer protection activities. The management strategy deliberates the preparedness of SMEs in production in handling the growth rate and production volume. During digitalization, the speed of information exchanges forces SMEs to accomplish market demands, product-customization, and fast processing time (De Carolis et al., 2017; Jing et al., 2020), thus requiring an efficient application innovative strategy creative and supported of smart technologies. Management quality and product creativity in BA reflects the SMEs' credibility towards digitalization. Hence, the strategies, resources and product-services, material selection, packaging, product variation, justification of market demands, distribution, and logistics are considered in ensuring the achievement of BA (De Carolis et al., 2017). Demographic conditions, characteristics, and cultures, and society's diverse economic levels boost Indonesia to be more selective in singling out appropriate strategies, management resources, categorizing, performing, and optimizing BA activities and functions. Besides, SMEs readiness is also elucidated on how the production protects the customer before and after product delivery (De Carollis, 2017) through the availability of consumers digital communication platform as product quality control, customer loyalty, and satisfaction services (Camilleri, 2018; Tak \& Panwar et al., 2015).

\subsubsection{Transaction (TC)}

TC, which involves text, sounds, and visual images to enhance services' production and innovation, is defined as commercial activities to transmit and treat digitized data (Ulas, 2019). Digital transformation embraces the utilization of the internet for data exchanges in product design, manufacturing, marketing, selling, presenting, and any data-based management model (Williams et al., 2018). Moreover, the internet economy, e-commerce, and social media trigger daily online transactions and communication platforms. Thus, it brings a significant contribution to personal economies (Scupola, 2009). Besides the transaction activities, SMEs' readiness towards digitalization is also gauged by technological leap or software and hardware updates. The flexibility of the strategy model, strategy approach, relationship maintenance, business transaction guidance, dan customers demand during the transaction is considered in ensuring the sustainability of business transaction practices (Hung et al., 2014). Therefore, software and hardware readiness, communication between hardware and software, and how information and data placed in by an unauthorized person, hacker, and external infiltration become a severe concern for SMEs and must be balanced with the needs and financial capabilities (Ilbiz \& Durst, 2019; Axmann \& Harmoko, 2020).

\subsubsection{Marketing (MC)}

MC is construed as ideas, products, services, technology, and refining ideas to fulfill a market opportunity, determining and satisfying the needs, market demands, and target markets' aspirations (Walsh \& Lipinski, 2009). SME's readiness refers to a firm's capability to effectively adopt and implement a change to counter the changing market trends (Weeks et al., 2004). In the digitalization era, digital technology in marketing practice can replace intuition, experience, theory, and brands to generate innovative customize products and optimize promotions on real-time bases of individual consumers (Cluley et al., 2019). The integration of data in marketing practice offers many benefits to the decision-making process (Cluley et al., 2019), forming customer knowledge management strategies and the dynamic ability to face the turbulence of the current business environment (Francesco et al., 2020; Suhendi et al., 2020). In addition, the adoption of technology in marketing practices and human resources concern on marketing skills, customers' social communication, and customer relationship management must be maintained well to assure the sustainability of SMEs in competitive advantages (Kotler, 2001; Adam et al., 2020).

\subsubsection{Management $(M G)$}

MG is designated as SMEs' willingness to plan, govern, organize, control, maintain, and sustain (De Carolis, 2017; Straatmann et al., 2016). Managerial expertise, trained staff, flexibility in strategy, operations, and adequate financial resources, are essential manifestations of organizational readiness to adopt change (Lai-Wan et al., 2020). Thus, the success of change management will implicate the assessment of SMEs readiness (Lou et al., 2019), including the deployment of change management, the techniques and strategic change management, the project management, the organizational resources, the managerial style, the communication and coordination and the change of technology penetration within these 
above movements (Margherita \& Petti, 2010). In the digitalization era, the integration of technology in managerial actions can be pervaded as a tool within strategic planning and formulation, complex decision-making, knowledge management, and top-down information flow to aid SMEs in performing the organization critically (Brady et al., 2008). The successful management change requires a large commitment from top management to provide leadership and empowerment, support, and change resources. High involvement of leaders, as well as the efficient and accurate method of communication, impact the creativity and energy of their employees, successful partnerships, colleagues, thus boosting the productivity of business (Randel et al., 2018). Inspired leaders can encourage employees to increase their work dedication and commitment to achieving organizational goals (Murnieks et al., 2016). Change management's success is carried out to maintain SMEs' sustainability in facing environmental demand (Straatmann et al., 2016).

\subsubsection{Micro-Environment (MI)}

MI is prescribed as an internal factor that directly affects SMEs' readiness towards digitalization. One of the influencer factors is the analysis of SMEs' strengths and weaknesses from staff, marketing systems, productivity, management, functions, and technology adoption. Thus, it crashes the SMEs' performance (Karman, 2020). The market demands, policy/strategy/vision, pricing, and licensing are also considered in this indicator (Kotler, 2000; Straatmann et al.,2016). Staff engagement should be evaluated in the digitization of change management, policy concept, plan, vision, and goal achievement by disclosure of policies. (Lou et al., 2019). Thus, it collides with the role, responsibility, and achievement of organizational success (Parida \& Kumar, 2006).

\subsubsection{Macro Environment (MA)}

MA is exemplified as external factors outside SMEs that covers opportunities and threats in Strength Weaknesses Opportunities and Threats (SWOT) analysis as well as demographic, economic, technology, environmental, political, government support, cultural, and broader competitor landscape (Kotler, 2000; Pal \& Dhaliwal, 2020). For demographic, the deftness of digitalization is deliberated from personal internet users, particularly age, literacy rate, gender, income, culture, community, the population of locality, employment status, and domicile (Hanafizadeh et al., 2009; Pal \& Dhaliwal, 2020). The government regulation that abutment the discharge of internet access and websites, the occasion of technical infrastructure also conferred in this schema (Vankudothu, 2014).

Meanwhile, the technology views the readiness of SMEs towards digitalization from various factors as follows.

\subsubsection{Culture}

Culture is decided as social-culture, knowledge, innovation, attitude, and behavior to respond to digitalization (Carmen et al., 2020; Jutla et al., 2002; Straatmann, 2016; Wahyuni et al., 2020) emotionally. Besides, satisfaction, trust, and confidence in digital transformation can facilitate change management success. Therefore, the commitment of the key actors and leader empowerment and personal and employee involvement inclines the considered factors approaching cultural assessment success. Budhiraja (2019) stated that culturally determined on digitalization is highly subordinate on top management involvement, employee attributes and attitude, active involvement of employees, augmented social interaction, actual absenteeism, and turnover intentions, and systematize the changes (Chênevert et al., 2019; Chamanian et al., 2018).

\subsubsection{Education}

Education is defined as the readiness of hard and soft skills to prepare technology adoption of digitalization and transfer knowledge, creativity, and innovation (Jutla et al., 2002; Hanafizadeh, 2009; Straatmann, 2016). Chiara et al. (2020) stated that people without ICT skills and education would be nothing in the new era. The lack of e-skills will affect social and education, hamper lifelong learning, and up-skilling. Thus, it will decrease e-innovation and e-readiness abilities (Herdon et al., 2015).

\subsubsection{Financial Resources}

Financial Resources are characterized as the readiness of SMEs as well as finance, loans or capital assistance, grants, resources supported activities through training, seminars, or exhibitions. In addition, the reinforcement of external stakeholders such as government and investors on the arrangement of financial assistance will accelerate SMEs' digitalization. Hence, the partnership over the funding, profit sharing, and business network development can be an alternative way of backing the financial resources (Hooi, 2006). As declared by Wong et al. (2018), SMEs' ability to turn around their organizations is often constrained due to limited access to financial resources. Therefore, SMEs must develop the creativity and innovation of partnerships and cooperation networks in handling the restriction. In a nutshell, financial benefits of technology adoption must be clearly defined and acknowledged to obtain additional financial resources from 
others parties (Chamanian et al. (2018) and hand over the compassionate among them that IT innovation in digitalization depends upon the high cost and risks (Galligan \& Mansor, 2011).

\subsubsection{The Technical Infrastructure}

The technical infrastructure is explained as SMEs' readiness through the availability of IT infrastructure, hardware, and software in bolstering digitalization (Budhiraja, 2019; Al-Balushi et al., 2014; Suhendi et al., 2020). Time access and technical infrastructure usage are also discussed as considered factors in this dimension (Hooi, 2006; De Carolis, 2017; Hanafizadeh, P. et al., 2009).

Since the economic perspective associates the entire IT function of digitalization and culture, education, financial resources, and technical infrastructure, the mapping activities that present the relationship among the above viewpoints can be seen in conceptual model development, for example, the readiness of SMEs in business activity (BA) is examined through culture, education, financial resources, and technical infrastructure and the transformation of digitalization. This appraisal also administers the other indicators viz TC, MC, MG, MI, and MA, as depicted in Fig.1.

\begin{tabular}{|c|c|c|c|c|c|c|c|}
\hline \multirow{4}{*}{ 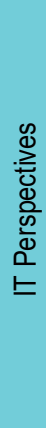 } & & BA & TC & $\mathrm{MC}$ & MG & MI & MA \\
\hline & Culture & BA-Culture & TC-Culture & MC-Culture & MG-Culture & MI-Culture & MA-Culture \\
\hline & $\begin{array}{c}\text { Financial } \\
\text { Resources }\end{array}$ & $\begin{array}{l}\text { BA-Financial } \\
\text { Resources }\end{array}$ & $\begin{array}{l}\text { TC-Financial } \\
\text { Resources }\end{array}$ & $\begin{array}{c}\text { MC-Financial } \\
\text { Resources }\end{array}$ & $\begin{array}{l}\text { MG-Financial } \\
\text { Resources }\end{array}$ & $\begin{array}{l}\text { MI-Financial } \\
\text { Resources }\end{array}$ & $\begin{array}{c}\text { MA-Financial } \\
\text { Resources }\end{array}$ \\
\hline & $\begin{array}{c}\text { Technical } \\
\text { Infrastructures }\end{array}$ & $\begin{array}{l}\text { BA-Technical } \\
\text { Infrastructures }\end{array}$ & $\begin{array}{l}\text { TC-Technical } \\
\text { Infrastructures }\end{array}$ & $\begin{array}{l}\text { MC-Technical } \\
\text { Infrastructures }\end{array}$ & $\begin{array}{l}\text { MG-Technical } \\
\text { Infrastructures }\end{array}$ & $\begin{array}{l}\text { MI-Technical } \\
\text { Infrastructures }\end{array}$ & $\begin{array}{l}\text { MA-Technical } \\
\text { Infrastructures }\end{array}$ \\
\hline
\end{tabular}

Fig. 1. A conceptual model for measuring the readiness of SMEs towards digitalization

\section{Research Activity}

This research consists of three main stages (See Fig. 2). The first stage relates to the development of conceptual models by exploring the problem identification. A series of activities inclusive of literature review and interview were delivered. The literature review is accomplished by studying performance measurement concepts, the several models of SMEs readiness from an economic and ICT perspective, investors' role, and the market place in accelerating SMEs' development. Some issues and challenges on SMEs' digitalization. The selection of references is based on the proximity of the topic to the research questions.

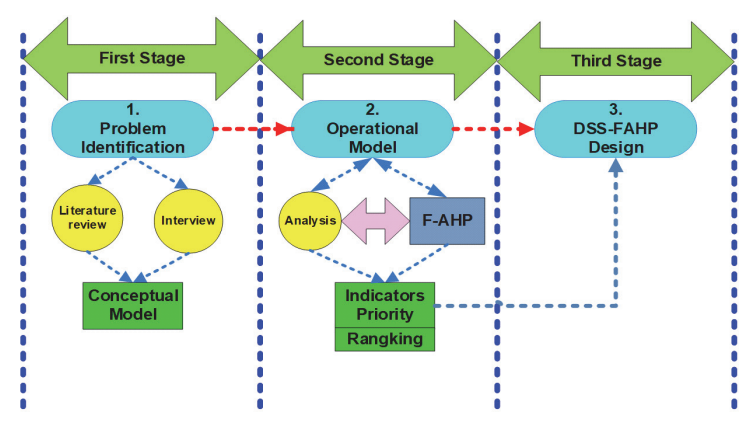

Fig. 2. Research schema

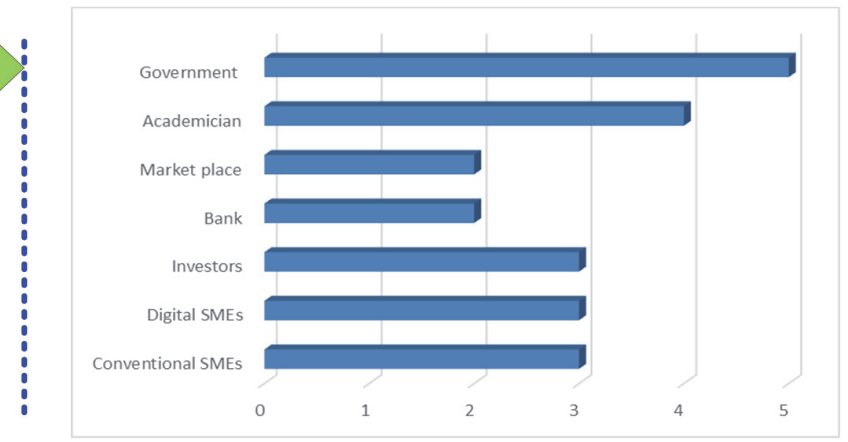

Fig. 3. Distribution of respondent

Furthermore, to strengthen the conceptual thinking, interviews with several stakeholders related to SMEs will be brought to a close. Two academicians in ICT and two economy expertise in SMEs were dialogued regarding the model. Division management leaders in the Ministry of Cooperatives and Small and Medium Enterprises and the Ministry of Communication and Information Technology in central Java, Indonesia, have observed their activities and discussed the proposed model perspectives. To understand the SMEs' problems and issues more closely, meetings with several marketplace business stakeholders in Indonesia, i.e., Tokopedia and blanja.com, were conducted. Moreover, a focus discussion with several investors such as Telecommunication company and Banking exhaustive the information gathering. The discussion covered the type of assistance program, the commitment and opportunities offered the barriers and challenges, the expected outcomes, and the target achievements. 
Face-to-face interviews (Creswell, 2007) are conducted online, and offline using the existing facilities and technology via WhatsApp application, video calls, or google meets. Thus, a more in-depth view of the supply chain and business life cycle process, success stories, various issues, and the data and information management are disclosed. The questions' format was made, leading to the conceptual model and supporting theories in this study. The quantitative content analysis (Stemler \& Steve, 2001) and qualitative data analytical practicing NVIVO software were applied to transcribe the literature reviews and interviews and understand the variables' relationship. NVIVO, as statistic data analytics, is capable of exploring the various meanings of words in data (Richards, 2002), understanding the gaps in data collection (Wickham \& Woods, 2005), and viewing the transparency of tacit knowledge in qualitative research (Samad \& Steven, 2018).

Hence, the indicators that compound the conceptual model were grouped into three recommendation levels as alternatives, namely low, middle, and high. These three levels are the general standard used to measure performance (Johnston et al.,2007). The "High" recommendations are handed out for each variable's and sub-variables' SME preparedness performs more than $50 \%$. The "Middle" suggestion complies when the achievement of variables and sub-variables at a score of 50:50. Meanwhile, the "Low" proposition is given to SMEs with a realization is less than 50\%. The analysis of the above classification is constructed through the development of the rubric. Performance-based rubric enables to capture and identify the essence of the model implementation and to attribute performance outcomes with strategic action. The rubric presented detailed information from all variables (Danks \& Allen, 2014). As a result, a conceptual model with the classification of recommendations based on the rubric was then defined. Herein, the model accommodates the SMEs and its stakeholders to decide the appropriate alternatives solutions and take corrective action in digitalization success.

The second stage is carried out to quantitatively operationalize the model by disseminating twenty-two questionnaires from academicians, government and offices, investors, the marketplace, banks, conventional SMEs, and digital SMEs. The respondents are asked for their multiple perspectives performing F-AHP analysis. The analysis inquiry was carried out to determine the level of importance and the weight of each variable in the DSS-SMEsReadiness model. Hsin-Pin and ShengWei (2009) discovered the Analytical Hierarchy Process (AHP) model as one effective and widely used Multi-Attribute Decision Making (MADM) method in resolving the significance of performance criteria in project measurement. AHP provides outstanding analytical into hierarchy criteria and sub-criteria levels for complex and unstructured problems (Özdağoğlu, 2007). AHP has an innate capacity to accommodate decision-makers' subjective judgment and multiple perspectives for dealing with multiple criteria decision-making problems. Okfalisa et al. (2018) have successfully exploited AHP in assigning priority values of Key Performance Indicators (KPIs) to allowancing and controlling organizational performance. Oudah et al. (2018) take advantage of AHP in identifying and prioritizing the various success factors linked to the sustainability of the large and medium-sized family business in the United Arab Emirates. In deciding the essential criteria and alternatives for suitable development of renewable energy in Indonesia, Rimantho et al. (2018) confidently interwove Interpretive Structural Modeling (ISM) and AHP. To deal with assessing the sustainable efficiency of Islamic banking, Lenny and Okfalisa (2019) have created a massive contribution of AHP. Meanwhile, Hwang et al. (2020) have been successfully applied AHP integrated with Analytical Network Process (ANP) to determine the weights of criteria as indicators for the manufacturing operation management model. The gap and discrepancies among the decision-makers in management levels were also determined by analyzing this model.

AHP estimates the judgment of decision-makers from a 1 to 9 scale. Thus, it gives preferences over a set of excellent alternatives selected. Nonetheless, the decision behaviours and rational thoughts are hard to pinpoint into a constraint scale. Consequently, the comparison matrices' consistency reflects the decision-makers' prudence launch incomplete (Liu et al., 2017). Thus, the irreconciled of the comparison matrix affects the acceptably persistent indicators. In a nutshell, AHP devoted the imprecise judgments of decision-makers close to the fuzziness (Chan \& Kumar, 2007; Özdağoğlu, 2007; Liu et al., 2017; Shaverdi et al., 2014). Therefore, the F-AHP method was matured for coping with the uncertain judgments of decision-makers (Naghadehi et al., 2009; Astanti et al., 2020) that expresses in fuzzy set numbers reflecting the vagueness of human thoughts, human thinking style, and linguistics terms (Liou et al., 2011; Dotun et al., 2016; Herrera \& HerreraViedma, 2000). Hence, F-AHP, as an extension of Saaty's theory, was sufficient in handling the satisfaction and significant level that are often vague and the hierarchical fuzzy problems (Shaverdi et al., 2014). Ioan et al. (2020) applied F-AHP by converting decision-makers' linguistic variables into triangular fuzzy to present the importance of evaluating manufacturing performance indicators. Hai-Min et al. (2020), employing F-AHP to establish a consistent judgment matrix in a new consulting process towards an adequate risk assessment model. Yazdi et al. (2018) accepted F-AHP to deliver a specific weight for particular experts in determining the fire and explosion model within the industrial process.

The distribution of respondents can be depicted in Fig. 3. The questionnaire was developed by putting the F-AHP approach with a Saaty scale from one to nine (Saaty, 2000; Özdağoğlu, 2007; Karima et al., 2012). The questionnaire equipped the respondents' appraisal on the comparison pairs of indicators. The expert judgment method was accomplished into a focus group discussion to minimize the ambiguity in filling out the questionnaire. The expert judgment equips a feature for obtaining the quantitative statements about uncertain quantities, several data source characteristics, and the subjectivity of expert knowledge and judgment. Expert judgment helps avoid bias, misleading, and nonreproducible results (Brownstein et al., 2019). In a nutshell, DSS-based F-AHP is then calculated in analyzing the questionnaires (Turban et al., 2011). The employment of DSS based F-AHP follows the formula as below (Özdağoğlu, A, 2007). 
It is structuring the hierarchy-based problem and pairwise matrix comparisons between criteria with the Triangular Fuzzy Number (TFN) scale to find the consistent ratio $(\mathrm{CR})$ values $(\mathrm{CR} \leq 0.1)$ on the comparison matrix. The calculations are considered essential for extracting the consistency of information from the real world and large-scale cases that are computationally expensive. TFN is a trapezoidal fuzzy number that is widespread in many literatures in F-AHP (Hossein et al., 2020; Zavadskas et al., 2020). TFN provides a linear mathematical model to weight the criteria and alternatives by fuzzy triangular numbers that are denoted merely as parameters $1, \mathrm{~m}$, and $\mathrm{u}(\mathrm{l} \leq \mathrm{m} \leq \mathrm{u})$ Respectively denote the smallest possible value, the best value, and the broadest possible values that describe a fuzzy function (Babak, 2012). Many ranking methods are defined for Fuzzy numbers that provide different ranking results (Boran et al., 2011). Meanwhile, TFN operates various functions, but only the significant operation is considered to be used. The fuzzy conversion scale is as in Table 1 (Prakash \& Mittra, 2003).

Table 1

Fuzzy Conversion Scale

\begin{tabular}{clc}
\hline Scale & TFN Scale & TFN Invers Scale \\
\hline 1 & $(1,1,1)$ & $(1,1,1)$ \\
2 & $(1 / 2,1,3 / 2)$ & $(2 / 3,1,2)$ \\
3 & $(1,3 / 2,2)$ & $(1 / 2,2 / 3,1)$ \\
4 & $(3 / 2,2,5 / 2)$ & $(2 / 5,1 / 2,2 / 3)$ \\
5 & $(2,5 / 2,3)$ & $(1 / 3,2 / 5,1 / 2)$ \\
6 & $(5 / 2,3,7 / 2)$ & $(2 / 7,1 / 3,2 / 5)$ \\
7 & $(3,7 / 2,4)$ & $(1 / 4,2 / 7,1 / 3)$ \\
8 & $(7 / 2,4,9 / 2)$ & $(2 / 9,1 / 4,2 / 7)$ \\
\hline
\end{tabular}

Furthermore, the value of the AHP comparison matrix will be changed into the F-AHP value.

\subsection{Step 2}

Calculating the value of Fuzzy Synthesis $(\mathrm{Si})$ :

$$
\begin{array}{ll}
\mathrm{Si}=\sum_{j=1}^{m} & M_{g i}^{j} x\left[\sum_{i=1}^{n} \sum_{j=1}^{m} M_{g i}^{j}\right]^{-1} \\
\text { explanation: } \\
\begin{array}{ll}
\mathrm{S}_{\mathrm{i}} & =\text { fuzzy synthesis value } \\
\mathrm{M} & =\text { TFN number } \\
\mathrm{m} & =\text { number of criteria } \\
\mathrm{i} & =\text { rows } \\
\mathrm{j} & =\text { column } \\
\mathrm{g} & =\text { parameter }(l, m, u)
\end{array}
\end{array}
$$

\subsection{Step 3}

Computing the vector value $(\mathrm{V}), M_{2}=\left(l_{2}, m_{2}, u_{2}\right) \geq M_{l}=\left(l_{1}, m_{1}, u_{1}\right)$ are defined as a vector value.

$$
\begin{aligned}
& \mathrm{V}\left(\mathrm{M}_{2} \geq \mathrm{M}_{1}\right)=\sup \left[\min \left(\pi \mathrm{M}_{1}(\mathrm{x})\right), \min \left(\pi \mathrm{M}_{2}(\mathrm{y})\right)\right] \\
& \mathrm{V}\left(\mathrm{M}_{2} \geq \mathrm{M}_{1}\right)=\left\{\begin{array}{l}
1 \quad \text { if } \mathrm{m}_{2} \geq \mathrm{m}_{1} \\
0 \quad \text { if } \mathrm{l}_{1} \geq \mathrm{u}_{2} \\
\frac{\mathrm{l}_{1}-\mathrm{u}_{2}}{\left(\mathrm{~m}_{2}-\mathrm{u}_{2}\right)-\left(\mathrm{m}_{1}-\mathrm{l}_{1}\right)}
\end{array}\right.
\end{aligned}
$$

\subsection{Step 4}

The calculation of De-fuzzification Ordinary Value (d').

For $\mathrm{k}=1,2, \mathrm{n} ; \mathrm{k} \neq \mathrm{I}$, we obtain the vector weight value:

$$
W^{\prime}=\left(d^{\prime}\left(A_{1}\right), d^{\prime}\left(A_{2}\right), \ldots . . d^{\prime}(A n)\right)^{T}
$$

\subsection{Step 5}

Normalization value of fuzzy vector weights $(W)$ estimation.

$$
\mathrm{d}\left(\mathrm{A}_{\mathrm{n}}\right)=\frac{\mathrm{d}^{\prime}}{\sum_{\mathrm{i}=1}^{\mathrm{n}} \mathrm{d}\left(\mathrm{A}_{\mathrm{n}}\right)}
$$


The normalized value of fuzzy vector weights deliberation.

$$
W=\left(d\left(A_{1}\right), d\left(A_{2}\right), \ldots, d(A n)\right)^{T}
$$

where $W$ is a non-fuzzy number.

\subsection{Step 6}

The calculation of the final weight of recommendation. This step is calculated by summing the multiplication of the criteria values against each alternative value. The third stage is organized by automating the DSS-based F-AHP into the prototype system development, namely DSS-SMEsReadiness. The system's mechanism declares several functions, including the rounding out of the questionnaire, the F-AHP weighting process, and recommendation analysis. The development of DSSSMEsReadiness is described in the system architecture designed. A prototype DSS-SMEsReadiness application was deployed using Hypertext Preprocessor (PHP) programming languages and Structured Query Language (MySQL) for a relational database management system. A Blackbox and User Acceptance Test (UAT) testing was attended to twenty-five respondents from the SMEs management leaders and experts to test its functionality.

\section{Results and Discussion}

\subsection{Analysis of DSS-F-AHP}

To operate the conceptual model, DSS-F-AHP was resolved by following the step activities at Eqs 1-6. As a result, Table 1 explained the summary of the calculation AHP eigenvector values, Table 2 described the recapitulation of fuzzy synthesis values, and Table 3 explicated the recapitulation of F-AHP weighted values. The structure of the hierarchy-based problem for the SMEs readiness model can be seen in Fig. 4.

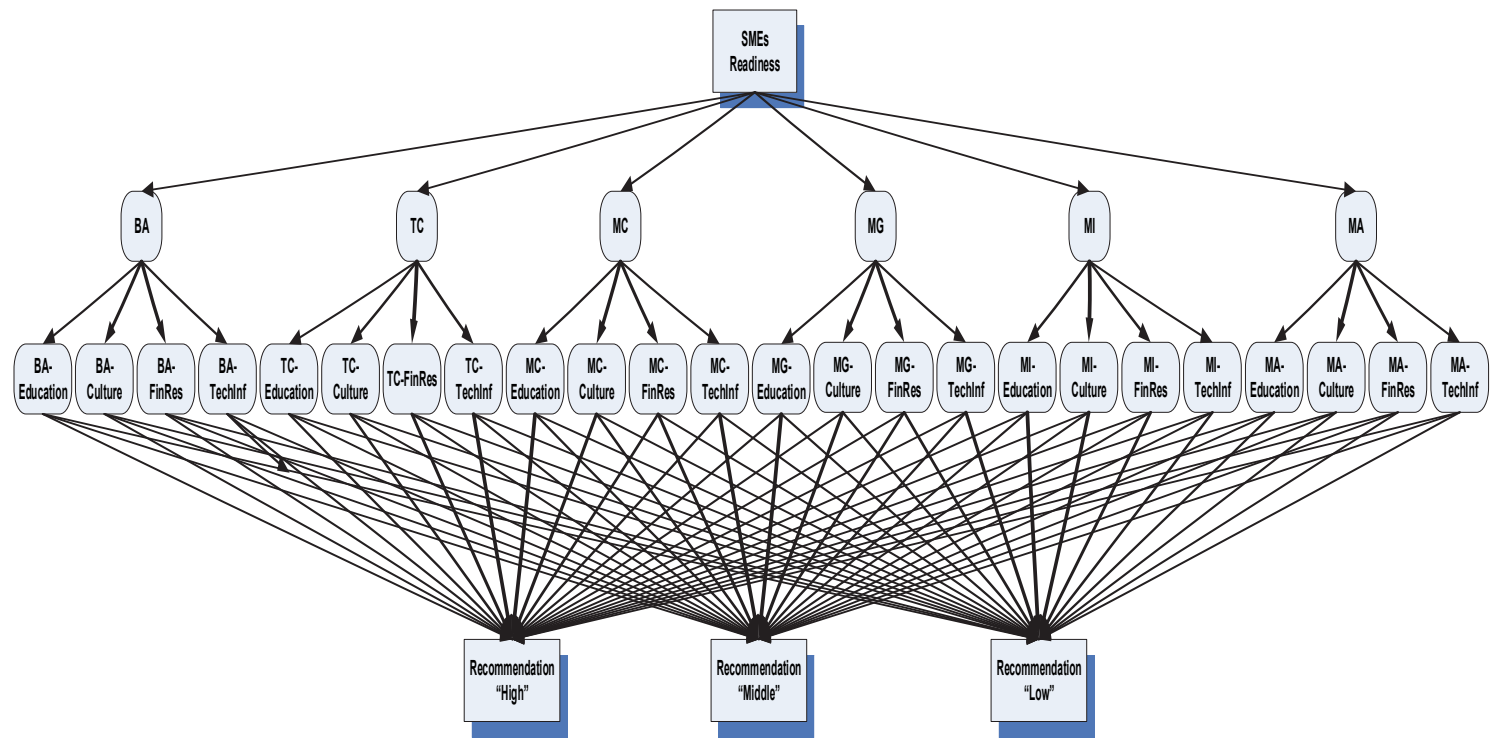

Fig. 4. The hierarchical structure of SMEs readiness model towards digital business

Table 2

The recapitulation of AHP eigenvector values

\begin{tabular}{|c|c|c|c|c|c|c|}
\hline No & Variable & $\begin{array}{l}\text { Normalization } \\
\text { (Eigen Vector) }\end{array}$ & CI & CR & RI & $\lambda$ maks \\
\hline 1 & Bisnis Activity (BA) & 0.05 & 0.10 & 0.08 & 1.24 & 6.51 \\
\hline 2 & Transaction (TC) & 0.29 & & & & \\
\hline 3 & Marketing (MC) & 0.22 & & & & \\
\hline 4 & Management (MG) & 0.15 & & & & \\
\hline 5 & Micro Environment (MI) & 0.22 & & & & \\
\hline 6 & Macro Environment (MA) & 0.07 & & & & \\
\hline
\end{tabular}


Table 3

The recapitulation of fuzzy synthesis values

\begin{tabular}{|c|c|c|c|c|c|c|c|c|}
\hline & No & $l$ & $m$ & $u$ & Sub Variable & $l$ & $m$ & $u$ \\
\hline \multirow[t]{4}{*}{1} & Bisnis Activity (BA) & 0.06 & 0.09 & 0.18 & BA-Culture & 0.09 & 0.14 & 0.25 \\
\hline & & & & & BA-Education & 0.25 & 0.41 & 0.62 \\
\hline & & & & & BA-Financial Resources & 0.16 & 0.28 & 0.49 \\
\hline & & & & & BA-Technical & 0.10 & 0.17 & 0.32 \\
\hline \multirow[t]{4}{*}{2} & Transaction (TC) & 0.09 & 0.17 & 0.31 & TC-Culture & 0.09 & 0.15 & 0.28 \\
\hline & & & & & TC-Education & 0.28 & 0.44 & 0.63 \\
\hline & & & & & TC-Financial Resources & 0.12 & 0.23 & 0.43 \\
\hline & & & & & TC-Technical Infrastructure & 0.10 & 0.18 & 0.43 \\
\hline \multirow[t]{4}{*}{3} & Marketing (MC) & 0.09 & 0.17 & 0.32 & MC-Culture & 0.10 & 0.18 & 0.35 \\
\hline & & & & & MC-Education & 0.19 & 0.35 & 0.58 \\
\hline & & & & & MC-Financial Resources & 0.13 & 0.26 & 0.51 \\
\hline & & & & & MC-Technical Infrastructure & 0.11 & 0.21 & 0.43 \\
\hline \multirow[t]{4}{*}{4} & Management (MG) & 0.08 & 0.16 & 0.29 & MG-Culture & 0.09 & 0.15 & 0.28 \\
\hline & & & & & MG-Education & 0.20 & 0.35 & 0.57 \\
\hline & & & & & MG-Financial Resources & 0.11 & 0.20 & 0.39 \\
\hline & & & & & MG-Technical Infrastructure & 0.17 & 0.30 & 0.53 \\
\hline \multirow[t]{4}{*}{5} & Micro Environment (MI) & 0.19 & 0.29 & 0.46 & MI-Culture & 0.13 & 0.17 & 0.32 \\
\hline & & & & & MI-Education & 0.14 & 0.28 & 0.46 \\
\hline & & & & & MI-Financial Resources & 0.13 & 0.16 & 0.26 \\
\hline & & & & & MI-Technical Infrastructure & 0.22 & 0.38 & 0.57 \\
\hline \multirow[t]{4}{*}{6} & Macro Environment (MA) & 0.06 & 0.11 & 0.21 & MA-Culture & 0.08 & 0.11 & 0.15 \\
\hline & & & & & MA-Education & 0.16 & 0.23 & 0.34 \\
\hline & & & & & MA-Financial Resources & 0.19 & 0.28 & 0.43 \\
\hline & & & & & MA-Technical Infrastructure & 0.25 & 0.38 & 0.55 \\
\hline
\end{tabular}

Before transforming into F-AHP, Table 2 was executed by following the AHP calculation. This table informed that the entire indicators provided consistent values as minimum standards $(C R \leq 0.1)$ and can be accepted in developing the SMEs Readiness Model. Following Eqs (1), (2), and (3), the fuzzy synthesis values as the result of TFN operation are derived in Table 3. Herein, the significant values of fuzzy operation are described the different priorities in more detail.

Table 4

The recapitulation of F-AHP priority weighted values $(W)$

\begin{tabular}{|c|c|c|c|c|}
\hline No & Variable & $\begin{array}{l}\text { Normalization Value } \\
\text { (Eigen Vector }-W \text { ) }\end{array}$ & Sub Variable & Normalization Value (Eigen Vector- $W$ ) \\
\hline \multirow[t]{4}{*}{1} & \multirow[t]{4}{*}{ Bisnis Activity (BA) } & \multirow[t]{4}{*}{0.02} & BA-Culture & 0.06 \\
\hline & & & BA-Education & 0.43 \\
\hline & & & BA-Financial Resources & 0.43 \\
\hline & & & BA-Technical Infrastructure & 0.14 \\
\hline \multirow[t]{4}{*}{2} & \multirow[t]{4}{*}{ Transaction (TC) } & \multirow[t]{4}{*}{0.30} & TC-Culture & 0.08 \\
\hline & & & TC-Education & 0.54 \\
\hline & & & TC-Financial Resources & 0.33 \\
\hline & & & TC-Technical Infrastructure & 0.13 \\
\hline \multirow[t]{4}{*}{3} & \multirow[t]{4}{*}{ Marketing (MC) } & \multirow[t]{4}{*}{0.24} & MC-Culture & 0.21 \\
\hline & & & MC-Education & 0.27 \\
\hline & & & MC-Financial Resources & 0.27 \\
\hline & & & MC-Technical Infrastructure & 0.26 \\
\hline \multirow[t]{4}{*}{4} & \multirow[t]{4}{*}{ Management (MG) } & \multirow[t]{4}{*}{0.20} & MG-Culture & 0.13 \\
\hline & & & MG-Education & 0.31 \\
\hline & & & MG-Financial Resources & 0.26 \\
\hline & & & MG-Technical Infrastructure & 0.31 \\
\hline \multirow[t]{4}{*}{5} & \multirow{4}{*}{$\begin{array}{l}\text { Micro Environment } \\
\text { (MI) }\end{array}$} & \multirow[t]{4}{*}{0.24} & MI-Culture & 0.19 \\
\hline & & & MI-Education & 0.36 \\
\hline & & & MI-Financial Resources & 0.09 \\
\hline & & & MI-Technical Infrastructure & 0.36 \\
\hline \multirow[t]{4}{*}{6} & \multirow{4}{*}{$\begin{array}{l}\text { Macro Environment } \\
\text { (MA) }\end{array}$} & \multirow[t]{4}{*}{0.03} & MA-Culture & 0.13 \\
\hline & & & MA-Education & 0.25 \\
\hline & & & MA-Financial Resources & 0.37 \\
\hline & & & MA-Technical Infrastructure & 0.37 \\
\hline
\end{tabular}


Meanwhile, the calculation of Eqs (4) to (6) at Table 4 elucidated the de-fuzzification of ordinary and fuzzy vector weights (w) values. Herein, Table 4 equips the recapitulation of priority weight value of indicator dan sub-indicators whereby the transaction (TS) contributes as the most significant indicator ( 0.30 of vector value) in measuring the readiness of SMEs digitalization following by Marketing (MC) and Micro Environment (MI) with a vector value of 0.24. Meanwhile, Management (MG) furnishes 0.20 of vector value, Macro Environment (MA), and Business Activity (BA) at the vector values of 0.03 and 0.02 , respectively. The weighted analysis for each sub-indicator is also defined. For instance, the TCEducation contributes as the significant sub-indicators of the transaction (TC) with the weight values in 0.54. TC-Financial Resource, TC-Technical Infrastructure then pursue it, and TC-Culture with the vector values in 0.33, 0.13, and 0.08, respectively. Therefore, SMEs and their stakeholders can identify each indicator's priority and sub-indicators towards measuring SMEs' digitalization readiness. Investigating the value of $\mathrm{CR}(\mathrm{CR} \leq 0.1)$ for the general component model, and each variable shows that this model and their constructed variables are consistent. Thus, this model is valuable and can be accepted in measuring the readiness of SMEs' digitalization.

Transaction (TC) develops into a "High" convincing component in assessing SMEs' readiness towards digitalization as well as educationally, financial resources, technical infrastructure, and culture. Digital transaction indulges the activities beyond the conventional one. Thus, it prioritizes fast, safe, trusted, accessible, customize, and flexible services on the road to customer satisfaction. Education and culture play significant roles in influencing the digital TC activities and scaling down the transaction risks, human fatal errors, and customer complaints. Therefore, human resources' competency in line with the digital skills for operating and managing the transaction can alter crucial factors on the success of transactions for the front land customers and the entire supply chain transaction. The transaction is also accomplished to archive the history flows of data and information exchanges of supply chain activities from the back and front desk. Thus, this repository eventually is a valuable component in flourishing big data analytics and a digital business data science platform. Lou (2019) stated that the automation of business and information processes in conjunction with system integration and data interchanges pass into a critical success for organizational new changes. The availability of business documentation and information repository as TC infrastructure treasures in data, application, and working systems bestow the employees to capture the organizational knowledge and adapt it to enhance the business process and encourage the right decision making for any emerging problems (Bacic \& Fadlalla, 2016). The interchange of data and information feeds into smart organizational management with low-risk decisions (Rainer \& Cegielski, 2011). Moreover, business and information automation and information alleviate the external stakeholders and supply chain in reinforcing the value-added services (Samaranayake, 2009).

In a nutshell, the collaboration with various partners is devoid of assuring transaction establishment sustainability, including the technology adoption buttoned-up system and technology integration. Thus, it is admitted to minimizing efforts and strengthen organizational business activity (Berente et al., 2009). Herein, leadership and top management support leading the organizational changes, digital work-culture, and networking development, pointing to digitalization become a reality. Focusing on the technology adoption, Moeuf et al. (2019) expounded that the data exploitation in big data analytics and cloud computing along the transaction activities has an influential charity in boosting the SMEs' performance. Besides, data recovery and data generation, and data mining can be used to measure the several values chosen throughout the product life cycle.

For rubric-based analytics, TC's high performance (more than $50 \%$ performance) must also be followed by comparable values for TC sub-variables, such as TC-Culture, TC-Education, TC-Financial Resources, and TC-technical infrastructure. Hence, the recommendation as corrective action will be given according to the accomplishment. As an example, SMEs with the measurement of its TC in "High" position will be suggested to revamp the business transaction activity by a high involvement of technology adoption, the expanded creativity and innovation thus it linearly collides to the effectiveness and efficiency of work procedures (Gressgard, 2011). The efforts to accomplish this must be taken into account by encouraging networking, collaboration partnerships, sharing benefits activities, and the funding request for TC-Financial Ressources and TC-Infrastructure. Reviewing the deed of TC-Education and TC-Culture, SMEs are advised to continue upgrading the entire management stakeholders' digital knowledge, and skills, notably for internal and market demands skills (Goerzig \& Bauernhansl, 2018). Transactions, rewards, incentives, discounts, and promotions in the supply chain activities are factored into the equation to create organizational concern in digital adoption (Al-Balushi et al., 2014). SMEs with the high condition of TC alters to a potential target for investors, governments, and outsiders to be subsidized and business capital, partnerships, and cultivated program approaching the success and sustainability of digitalization. Lou (2019) puts this high condition as seamless and advanced performance. A position where SMEs run full automation of the business process, activity focused on the augmenting of accuracy, effectiveness, less error, cost reduction, transparency, and work efficiency.

Meanwhile, SMEs with the value of TC readiness in the "Middle" level (the performance is 50:50) will be followed by the realization of TC-Education, TC-Culture, TC-Financial Resources, and TC-Infrastructure minimum at 50:50. In this situation, SMEs proposes to make various improvements to the entire supply chain transaction activities. The focus on digital technology adoption must be serious attention by management leaders to perform TC-Education, TC-Culture, TCFinancial Resource, and TC-Infrastructure. Open-minded leaders into technology innovation, creativity, partnerships, and networking contribute significantly to transaction success. Moeuf et al. (2019) found that managers and external experts supported a prominent role in the success and failure of a digitalization SME project (Budhiraja, 2019). Randel et al. (2018) 
reinforce by investigating how leaders' leadership and empowerment with external stakeholders and employees boost business production success. Lack of management, business, technical, and technology adoption skills and lack of resources are considered growing into the main risk in SMEs' digitalization (Goerzig \& Bauernhansl, 2018; Rauch et al., 2017). SMEs with "Low" performance of TC as well as TC-Education, TC-Culture, TC-Financial Resources, and TCInfrastructure with the values are less than $50 \%$ indicate that their business transaction and supply chain activities are far from automation, data integration, and technology adoption. Unfortunately, digitalization among management and stakeholders is premeditated, but it is un-optimal to realize the supply chain transactions. Lack of networking and partnerships, creative and innovative thinking, technology and digital adoption, and limited standard production just for day to day business is detected in this quadrant. Lou (2019) states this situation as a non-existence condition of SMEs with untouchable technology, un well-reviewed automatic system initiation, and un-professional business activity (BA), transaction (TC), marketing (MC), management (MG), microenvironment (MI), and macro environment (MA). In a nutshell, this accustom tightens the SMEs on conducting considerable endeavors towards digitalization success. Meanwhile, this level of SMEs requires adequate financial assistance and funding programs to empathize with SMEs' business models, strategies, processes, people, and technology-supported digitalization.

\subsection{The Application Design of DSS-SMEs Readiness}

The system architecture for DSS-SMEsReadiness can be seen in Fig. 5. The design is created according to the DSS components, namely management model, knowledge-based management of criteria and alternatives, and interface design of input and output. The activity pursues the mechanism of DSS based F-AHP staring from the weighting values assessment by respondents, F-AHP analytical process, and ending by the demonstration of indicators and recommendation performance analysis for decision-makers as end-users. This prototype system is created by pursuing the model life cycle based on objectoriented. Two types of users are initiated in accessing the application, namely administrators and managers. An administrator is in charge of executing DSS-SMEsReadiness components, including the criteria, sub-criteria, alternatives, questionnaire, recommendations, users, and model-driven DSS using F-AHP. Meanwhile, the managers are the external and internal stakeholders that have significant contributions to SMEs' evolution in policies, regulations, managerial, finance, and beneficial activities or projects such as government, investors, academicians, marketplaces, and SMEs' managers and owners. They are asked their opinions and perspectives to weigh the modeling instruments and F-AHP questionnaire on a nine scale. Besides, the managers are of assistance with the final calculation of F-AHP with the numbers of priority indicators in measuring the SMEs' readiness model. The mapping conditions of performance leveling in the low, middle, and high achievement of each indicator analysis are also conferred. This system is designed the dynamic database management models that allow expanding the proposed indicators in SMEs' readiness model development. The calculation of F-AHP can be adjusted based on the numbers of indicators and perspectives of users. The system interfaces can be depicted in Fig. 6 and 7.

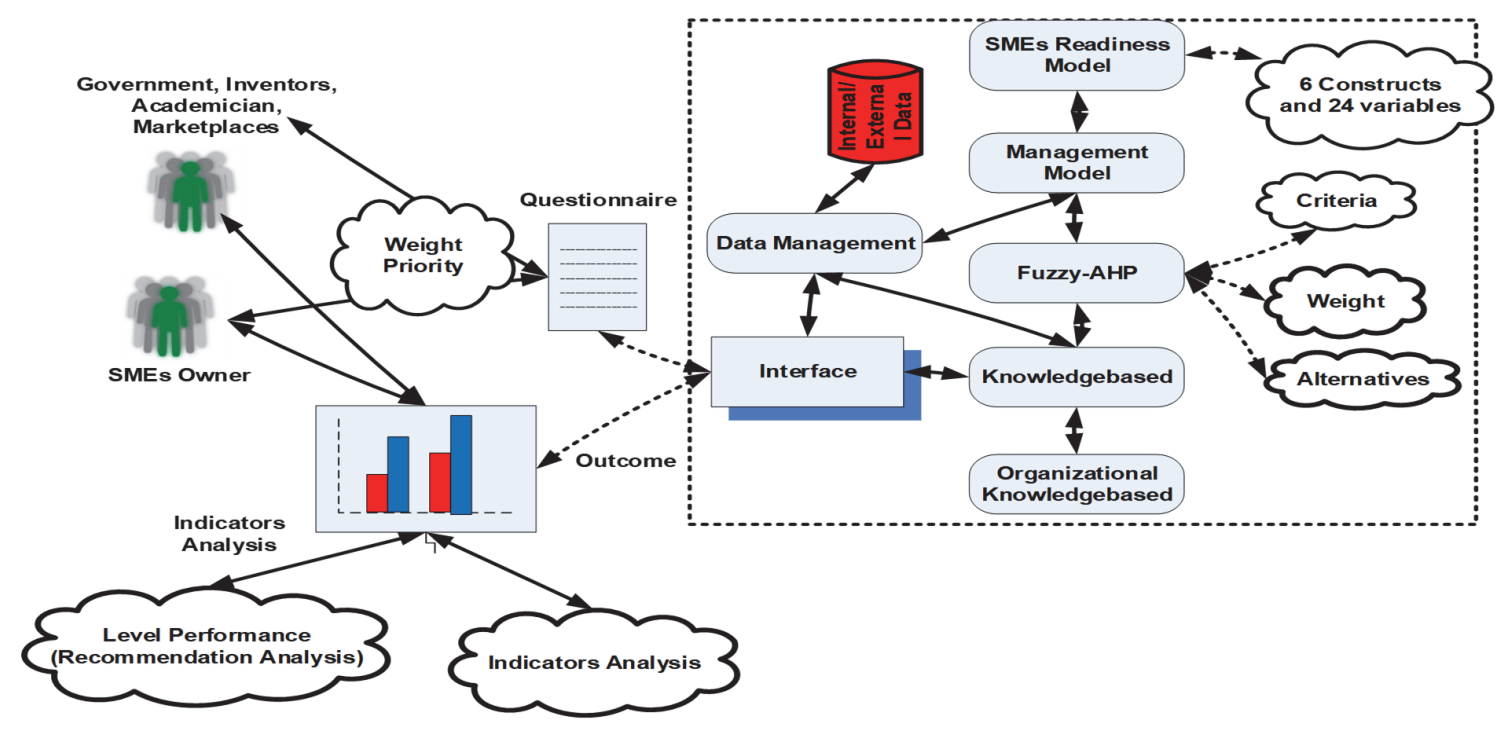

Fig. 5. Architecture designed for DSS-SMEsReadiness

A BlackBox testing showed that the entire related functions have been running well following the expected output. UAT testing asked the respondents regarding the system interface, the user-friendly system, the justification of system analysis, and provided system analysis benefits. This test acknowledged that $98 \%$ of respondents agree that this DSS-SMEsReadiness application can help identify the success factors of SMEs' readiness towards digitalization. The recommendation inquiry hands over a knowledge transfer and acquisition close to the digitalization success. 


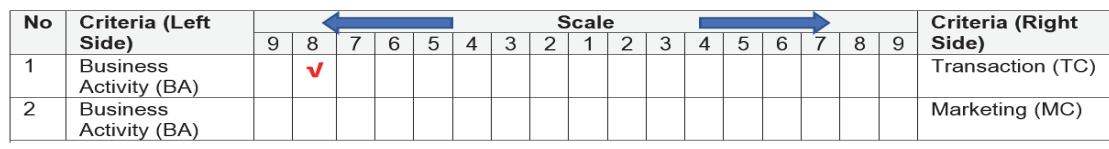
Construct: Economic Business Perspectives

\begin{tabular}{|c|c|c|c|c|c|c|c|c|c|c|c|c|c|c|c|c|c|c|c|}
\hline No & Criteria (Left & & & & & 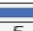 & & & & Scal & & & & & & $\Rightarrow$ & & & Criteria (Right \\
\hline & Side) & 9 & 8 & 7 & 6 & 5 & 4 & 3 & 2 & 1 & 2 & 3 & 4 & 5 & 6 & 7 & 8 & 9 & Side) \\
\hline 1 & Business & & & & & & & & & & & & & & & & & & Transaction (TC) \\
\hline 2 & $\begin{array}{l}\text { Business } \\
\text { Activity (BA) }\end{array}$ & & & & & & & & & & & & & & & & & & Marketing (MC) \\
\hline 3 & $\begin{array}{l}\text { Business } \\
\text { Activity (BA) }\end{array}$ & & & & & & & & & & & & & & & & & & Management (MG) \\
\hline 4 & $\begin{array}{l}\text { Business } \\
\text { Activity (BA) }\end{array}$ & & & & & & & & & & & & & & & & & & $\begin{array}{l}\text { Micro Environment } \\
\text { (MI) }\end{array}$ \\
\hline 5 & $\begin{array}{l}\text { Business } \\
\text { Activity (BA) }\end{array}$ & & & & & & & & & & & & & & & & & & $\begin{array}{l}\text { Macro Environment } \\
\text { (MA) }\end{array}$ \\
\hline 6 & $\begin{array}{l}\text { Transaction } \\
\text { (TC) }\end{array}$ & & & & & & & & & & & & & & & & & & Marketing (MC) \\
\hline 7 & $\begin{array}{l}\text { Transaction } \\
\text { (TC) }\end{array}$ & & & & & & & & & & & & & & & & & & Management (MG) \\
\hline 8 & $\begin{array}{l}\text { Transaction } \\
\text { (TC) }\end{array}$ & & & & & & & & & & & & & & & & & & $\begin{array}{l}\text { Micro Environment } \\
\text { (MI) }\end{array}$ \\
\hline 9 & $\begin{array}{l}\text { Transaction } \\
\text { (TC) }\end{array}$ & & & & & & & & & & & & & & & & & & Macro Environment \\
\hline 10 & $\begin{array}{l}\text { Marketing } \\
\text { (MC) }\end{array}$ & & & & & & & & & & & & & & & & & & Management (MG) \\
\hline 11 & $\begin{array}{l}\text { Marketing } \\
\text { (MC) }\end{array}$ & & & & & & & & & & & & & & & & & & $\begin{array}{l}\text { Micro Environment } \\
\text { (MI) }\end{array}$ \\
\hline
\end{tabular}

Fig. 6. Interface designed of DSS-SMEsReadiness for questionnaire page

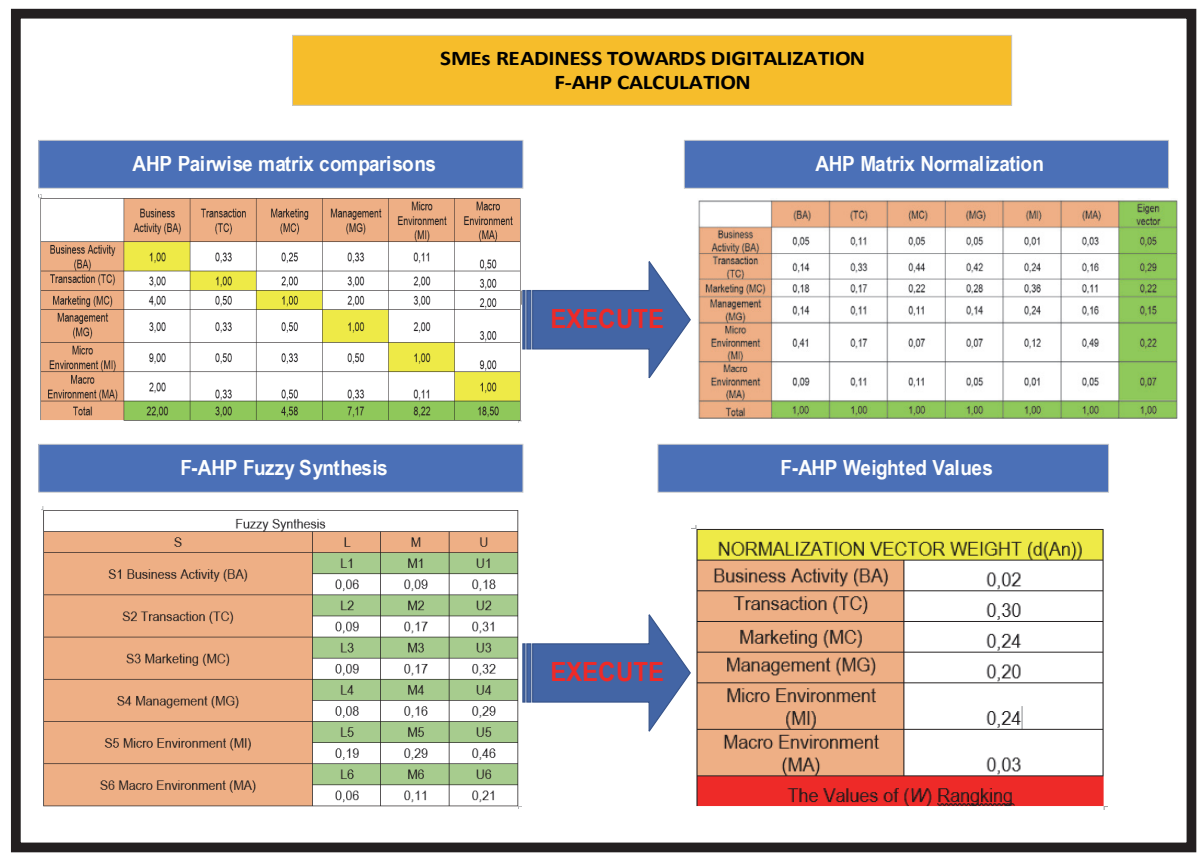

Fig. 7. Interface designed of DSS-SMEsReadiness for F-AHP weighted page

\section{Conclusion}

This study has succeeded in identifying the triumphant factor in measuring the readiness of SMEs towards digitalization. The SMEs Readiness model was built by considering external and internal stakeholders' perspectives as a side of economic activities and IT support in accelerating the success of digital adoption. Six constructs establish this model with twenty-four sub-variables. DSS-F AHP has been successfully analyzed that the Transaction construct (TC) ripen into the most playing actor in measuring SMEs' readiness towards digitalization. To optimal achieve the TC performance, TC-Education must be conditioned in high enforcement following by TC-Financial Resource, TC-Infrastructure, and TC-culture, respectively. Besides TC, DSS-based F-AHP weighs the priority values of Marketing (MC), Micro Environment (MI), Management 
(MG), Macro Environment (MA), and Business Activity (BA), respectively, as influencer indicators of SMEs readiness. The values of sub-variables for each construct are also defined in this model. Hence, the DSS-SMEsReadiness model equips the analysis of recommendation as an alternative solution according to the rubric classification in low, middle, and high categories. This DSS-SMEsReadiness model lets the SMEs estimate their enforcement through self-assessment of SMEs' readiness towards digitalization. Knowledge transfer and acquisition from the multiple perspectives enrich this model and meet the SMEs' demands theoretically and practically. Besides, the proposed recommendation advocacy SMEs in making the right decisions and corrective actions and the business strategy development, target achievement, and vision, focused on SMEs' digitalization. Moreover, this model also administers a guideline for external stakeholders to offer the policy and regulation, funding, partnerships, and sophisticated assistance program in encouraging the digital transformation for SMEs. Thus, the risk of investment and digitalization deficiency can be minimized.

\section{Acknowledgment}

This study received a grant from Universitas Islam Negeri Sultan Syarif Kasim Riau Indonesia through the DIPA funding number. 1171 / R / 2019. The authors would like to send the appreciation for the support parties in this study, including the Ministry of Cooperatives and Small and Medium Enterprises, the Ministry of Communication and Information Technology, management of market places, Telecommunication Company at Pekanbaru and Central Jakarta, Department of Communication, Informatics and Statistics of Riau Province, Integrated Business Services Center of Riau Province, Central Banks, Faculty of Science and Technology, Faculty of Economics and Social Sciences of Universitas Islam Negeri Sultan Syarif Kasim Riau, and several SMEs in Riau Province.

\section{References}

Adam, M., Ibrahim, M., Ikramuddin., \& Syahputra, H. (2020). The role of digital marketing platforms on supply chain management for customer satisfaction and loyalty in small and medium enterprises (SMEs) at Indonesia. International Journal Supply Chain Management, 9(3), 1210-1220.

Al-Balushi, S., Sohal, A. S., Singh, P. J., Al Hajri, A., Al Farsi, Y. M. \& Al Abri, R. (2014). Readiness factors for lean implementation in healthcare settings-A literature review. Journal of Health Organization and Management, 28(2), $135-153$.

AlMaimani., J. \& Fuadah, J. (2015). Enhancing Active Participation of SMEs and Islamic Banks Towards Economic Diversification in Oman, International Accounting And Business Conference, IABC. Elsevier Journal, 31, $677-688$.

Amir, M., \& Yusuf, M. H. (2020). Characteristics of Islamic entrepreneurship and the business success of SMEs in Indonesia. Journal of Entrepreneurship Education, 23(2), 1-16.

Anjar, P., Abdul, M., \& Vera, N. A. O. (2020). Identifying digital transformation paths in the business model of SMEs during the COVID-19 Pandemic. Journal of Open Innovation: Technology, Market, and Complexity, 6(4), 104.

Astanti, D. R., Mbolla, E. S., \& Ai, J. (2020). Raw material supplier selection in a glove manufacturing: Application of AHP and fuzzy AHP. Decision Science Letters, 9(2020), 291-312.

Axmann, B., \& Harmoko, H. (2020). Robotic process automation: An overview and comparison to other technology in industry 4.0. In 2020 10th International Conference on Advanced Computer Information Technologies (ACIT) (pp. 559562).

Babak, D. R. (2012). Selecting the best supplier using analytic hierarchy process (AHP) method. African Journal of Business Management, 6(4), 1455-1462.

Bacic, D., \& Fadlalla, A. (2016). Business information visualization intellectual contributions: An integrative framework of visualization capabilities and dimensions of visual intelligence. Decision Support Systems, 89, 77-86.

Barnard, J., Dawe, E. N., Dolan, M. J., \& Rajcic, N. (2017). Parton shower uncertainties in jet substructure analyses with deep neural networks. Physical Review D, 95(1), 1-9.

Berente, N., Vandenbosch, B., \& Aubert, B. (2009). Information flows and business process integration. Business Process Management Journal, 15(1), 119-141.

Berry, A., Edgard, R., \& Henry, S. (2001). Small and medium enterprise dynamics in Indonesia. Bulletin of Indonesian Economics Studies, 37(3), 363-384.

Bokovec, K. T. D., \& Rajkovic, T. (2015). Evaluating ERP Projects with multi-attribute decision support systems. Comput. Ind, 73, 93-104.

Boran, F. E., Genç, S., \& Akay, D. (2011). Personnel selection based on intuitionistic fuzzy sets. Human Factors and Ergonomics in Manufacturing \& Service Industries, 21(5), 493-503.

Brady, M., Fellenz, M. R., \& Brookes, R. (2008). Researching the role of information and communications technology (ICT) in contemporary marketing practices. Journal of Business and Industrial Marketing, 23(2), 108-114.

Bridges.org. (2017). E-readiness assessment: Who is doing what and where? Cape Town. Retrieved from http://www.bridges.org/files/active/0/ereadiness_whowhatwhere_bridges.pdf.

Brownstein, N. C., Louis, T. A., O’Hagan, A., \& Pendergast, J. (2019). The Role of Expert Judgment in Statistical Inference and Evidence-Based Decision-Making. American Statistician, 73(sup1), 56-68.

Budhiraja, S. (2019). Organizational readiness for change: an in- herent concern for Indian small and medium enterprises (SMEs). Development and Learning in Organizations, 33(2), 4-7. 
Camilleri M.A. (2018) Market Segmentation, Targeting and Positioning. In: Travel Marketing, Tourism Economics and the Airline Product. Tourism, Hospitality \& Event Management. Springer, Cham. https://doi.org/10.1007/978-3-31949849-2 4.

Carmen, I., Frank, T., Kai-Michael, G., \& Corrado, T. (2020). The relationship between organizational culture, sustainability, and digitalization in SMEs: A systematic review. Journal of Cleaner Production, 275 (December), 122944.

Chamanian, S., Uluşan, H., Koyuncuoğlu, A., Muhtaroğlu, A., \& Külah, H. (2018). An adaptable interface circuit with multistage energy extraction for low-power piezoelectric energy harvesting MEMS. IEEE Transactions on Power Electronics, 34(3), 2739-2747.

Chan, F. T. S. \& Kumar, N. (2007). Global supplier development considering risk factors using fuzzy extended AHP-based approach, Omega. 35, 417-431.

Chênevert, D., Kilroy, S., \& Bosak, J. (2019). The role of change readiness and colleague support in the role stressors and withdrawal behaviors relationship among health care employees. Journal of Organizational Change Management, 32(2), 208-223.

Chiara, E. De. M., Ierene, M., Alberto, Di., M. (2020). European SMEs's engagement in open innovation when the important thing is to win and not just to participate, what should innovation policy do? Technological Forecasting and Social Change, 152(March), 119843.

Cluley, R., Green, W., \& Owen, R. (2020). The changing role of the marketing researcher in the age of digital technology: Practitioner perspectives on the digitization of marketing research. International Journal of Market Research, 62(1), 2742.

Coreynen, W., Matthyssens, P., \& Van, B. W. (2017) Boosting servitization through digitization: Pathways and dynamic resource configurations for manufacturers. Industrial Marketing Management, 60, 42-53.

Creswell, J.W. (2014). Research Design: Qualitative, Quantitative and Mixed Methods Approach (4 ${ }^{\text {nd }}$ ed.). London: Sage.

Danks, S., \& Allen, J. (2014). Performance-Based Rubrics for Measuring Organizational Strategy and Program Implementation. Performance Improvement Quarterly, 27(1), 33-49.

De Carolis, A., Macchi, M., Negri, E. \& Terzi, S. (2017). A maturity model for assessing the digital readiness of manufacturing companies, in Lödding, H., Riedel, R., Thoben, KD, von Cieminski, G. \& Kiritsis, D. (Ed.), Advances in Production Management Systems. The Path to Intelligent, Collaborative and Sustainable Manufacturing. APMS 2017.

IFIP Advances in Information and Communication Technology, Springer, Cham, pp. 13-20.

Dotun, A., Laosirihongthong, T., \& Premaratne, S. (2016). Prioritizing lean supply chain management initiatives in healthcare service operations: a fuzzy AHP approach. Journal Production Planning and Control, 27(12), April.

Dubruc N., Peillon S., Farah A. (2014). The impact of servitization on corporate culture. Procedia CIRP, 16, $289-94$.

Enge, M., Arda, H. E., Mignardi, M., Beausang, J., Bottino, R., Kim, S. K., \& Quake, S. R. (2017). Single-Cell Analysis of Human Pancreas Reveals Transcriptional Signatures of Aging and Somatic Mutation Patterns. Cell, 171(2), 321-330.

Fadiya, O., Georgakis, P., Chinyio, E., \& Nwagboso, C. (2015). Decision-making framework for selecting ICT-based construction logistics systems. Journal of Engineering, Design and Technology, 13(2), 260-281.

Francesco, O., Francesco, J. O, \& Angela, P. (2020). A mobile clinical DSS based on augmented reality and deep learning for the home cares of patients afflicted by bedsores. Procedia Computer Science, 175(2020), 181-188.

Galligan, J., \& Mansor, D. (2011). Cloud computing for SMEs in Malaysia: Unlocking the potential of cloud computing for a new world of business. myForesight, 32-33.

Goerzig, D., \& T. Bauernhansl. (2018). Enterprise Architectures for the Digital Transformation in Small and Medium-sized Enterprises. Procedia CIRP, 67, 540-545.

Gressgard, L. J. (2011). Virtual team collaboration and innovation in organizations. Team Performance Management. 17(1/ 2), 102-119.

Hai-Min, L., Wen-Juan, S., Shui-Long, S., \& An-Nan, Z. (2020). Risk assessment using a new consulting process in Fuzzy AHP. Journal of Construction Engineering and Management, 146(3), March.

Hanafizadeh, P., Hanafizadeh, M. R., \& Khodabakhshi, M. (2009). Taxonomy of e- readiness assessment measures. International Journal of Information Management, 29(3), 189-195.

Helversen, B. V., Katarzyna, A., Wieslaw, K., Radoslaw, N. (2018). Influence of consumer reviews on online purchasing decisions in older and younger adults. Decision Support Systems Journal, 113, 1-10.

Herdon, M., Botos, S., \& Várallyai, L. (2015). Decreasing the digital divide by increasing e-innovation and e-readiness abilities in agriculture and rural areas. International Journal of Agricultural and Environmental Information Systems, $6(1), 1-18$.

Herrera, F., \& Herrera-Viedma, E. (2000). Linguistic decision analysis: steps for solving decision problems under linguistic information. Fuzzy Sets and systems, 115(1), 67-82.

Hoellthaler, G., Braunreuther, S., \& Reinhart, G. (2018). Digital Lean Production-An Approach to Identify Potentials for the Migration to a Digitalized Production System in SMEs from a Lean Perspective. Procedia CIRP, 67, 522-527.

Hooi, L. W. (2006). Implementing e-HRM: the readiness of small and medium sized manufacturing companies in Malaysia. Asia Pacific Business Review, 12(4), 465-485.

Hossein, K., Mohsen, S., \& Majid, J. (2020). A fully fuzzy best-worst multi attribute decision making method with triangular fuzzy number: A case study of maintenance assessment in the hospitals. Applied Soft Computing, 86(January), 105882. 
Hsin-Pin, F., \& Sheng-Wei, L. (2009). Applying AHP to Analyze Criteria of Performance Measurement for National Energy Promotion Project. International Journal of Electronic Business Management, 7(1), 70-77.

Hung, W. H., Chang, L. M., Lin, C. P., \& Hsiao, C. H. (2014). E-readiness of website acceptance and implementation in SMEs. Comput. Human Behavior, 40, 44-55.

Hwang, G., Jun-Hee, H., \& Tai, W. C. (2020). An integrated key performance measurement for manufacturing operations management. Sustainability Journal, 12, 5260.

Ilbiz, E., \& Durst, S. (2019). The Appropriation of Blockchain for Small and Medium-sized Enterprises. Journal of Innovation Management, 7(1), 26-45.

Ioan, B. A., Iuliana, B. O., Bogdan, V., Sabau, P. D. C., \& Tuse, D. (2020). Performance evaluation model of Romanian manufacturing listed companies by fuzzy ahp and topsis. Technological and Economic Development of Economy, 26(4), 808-836.

Jing, L., Chien-Wen, C., Chi-Hui, W., Hsing-Chun, H., \& Ching-Torng, L. (2020). How do partners benefit from IT use in supply chain management: An empirical study of Taiwan's bicycle industry, sustainability, 12(7), 2883.

Johnston, J., Tomlinson, H.B., and Susan, H. (2007). The Assessment: Developmental Child Case Study. Developmental Child Case Study: Example Assessment, Rubrics, and Data Tables for NAEYC. NCATE Program Report.

Jutla, D., Bodorik, P., \& Dhaliwal, J. (2002). Supporting the e-business readiness of small and medium-sized enterprises: Approaches and metrics. Internet Research, 12(2), 139-164.

Karima, Z., Abdellah, A., \& Sanae, K. (2012). Applying fuzzy analytic hierarchy process (FAHP) to evaluate factors locating emergency logistics platforms. International Journal of Computer Applications, 57(21), 17-23.

Karman, A. (2020). Towards crystallizing circular business models: A critical analysis of literature. Journal of Sustainability Science and Management, 15(6), 175-194.

Khalfan, M. M. A., Anumba, C. J., \& Carrillo, P. M. (2001). Development of a readiness assessment model for concurrent engineering in construction. Benchmarking: An International Journal, 8(3), 223-239.

Klein, M. M., Biehl, S. S., \& Friedli, T. (2018). Barriers to smart services for manufacturing companies - an exploratory study in the capital goods industry. Jnl of Bus \& Indus Marketing, 83(10), 131.

Kominfo. (2020, November 1). Pengguna Internet Indonesia Nomor Enam Dunia. Retrieved from https://kominfo.go.id/content/detail/4286/pengguna-internet-indonesia-nomor-enam-dunia/0/sorotan media.

Kotler, P. (2000). Marketing Management, Millenium Edition. USA: Prentice-Hall.

Kuckertz, A., Brändle, L., Gaudig, A., Hinderer, S., Morales Reyes, C. A., Prochotta, A., ... Berger, E. S. C. (2020). Startups in times of crisis - A rapid response to the COVID-19 pandemic. Journal of Business Venturing Insights, 13(June), e00169.

Lai-Wan, W., Lai-Ying, L., Jun-Jie, H., Wei-Han, G., \&Keng-Boon, O. (2020). Time to seize the digital evolution: Adoption of blockchain in operations and supply chain management among Malaysian SMEs. International Journal of Information Management, 52(June), 101997.

Leny, N., \& Okfalisa. (2019). Measuring the sustainability performance of Islamic banking in Indonesia, Journal Social Science and Humanities, 27(2), 1073-1090.

Lerch, R. N., Baffaut, C., Kitchen, N. R., \& Sadler, E. J. (2015). Long-Term Agroecosystem Research in the Central Mississippi River Basin: Dissolved Nitrogen and Phosphorus Transport in a High-Runoff-Potential Watershed. Journal of Environmental Quality, 44(1), 44-57.

Liang, G., Yinghong, S. W., Ruchi, S., \& Rong, K. (2017). Investigating e-business models' value retention for start-ups: The moderating role of venture capital investment intensity. International Journal of Production Economics, 186, 3345.

Liou, J. J. H., Wang, H. S., Hsu, C. C., \& Yin, S. L. (2011). A hybrid model for selection of an outsourcing. Applied Mathematical Modelling, 35(10), 5121-5133.

Liu, F., Peng, Y., Zhang, W., \& Pedrycz, W. (2017). On consistency in AHP and Fuzzy AHP. J. Syst. Sci. Inf, 5(2), 128147.

Lou, E. C. W., \& Goulding, J. S. (2010). The pervasiveness of e-readiness in the global built environment arena. Journal of Systems and Information Technology, 12(3), 180-195.

Lou, E. C. W., Lee, A., \& Goulding, J. (2019). E-readiness in construction (ERiC): self-assessment framework for UK small and medium enterprise building services providers. Architectural Engineering and Design Management, 16(1), 3-22.

Margherita, A., \& Petti, C. (2010). ICT-enabled and process-based change: An integrative roadmap. Business Process Management Journal, 16(3), 473-491.

Matt, C., Hess, T., \& Benlian, A. (2015). Digital transformation strategies. Business \& Information Systems Engineering, 57(5), 339-343.

Medini, K., \& Bourey, J. P. (2012). SCOR-based enterprise architecture methodology, International Journal of Computer Integrated Manufacturing, 25(7), 594-607.

Mittal, S., M. A. Khan., D. Romero., \& T. Wuest. (2018). A Critical Review of Smart Manufacturing \& Industry 4.0 Maturity Models: Implications for Small and Medium-sized Enterprises (SMEs). Journal of Manufacturing Systems. 49, 194 214.

Moeuf, A., Lamouri, S., Pellerin, R., Tamayo-Giraldo, S., Tobon-Valencia, E., \& Eburdy, R. (2019). Identification of critical success factors, risks and opportunities of Industry 4.0 in SMEs. International Journal of Production Research, 58(5), 1384-1400. 
Muller, P., Robin, N., Jonathan, S., Braun, H., Sophie, L., Farrenkopg, J., ... Pedersen, B. (2019, November 26). Annual Report on European SMEs by SMEs - Background Document. Retrieved from https://ec.europa.eu/growth/smes/smestrategy/performance-review en.

Murnieks, C. Y., Cardon, M. S., Sudek, R., White, T. D., \& Brooks, W. T. (2016). Drawn to the fire: The role of passion, tenacity and inspirational leadership in angel investing. Journal of Business Venturing, 31(4), 468-484.

Naghadehi, M. Z., Mikaeil, R., \& Ataei, M. (2009). The application of fuzzy analytic hierarchy process (FAHP) approach to selection of optimum underground mining method for Jajarm Bauxite Mine, Iran. Expert Systems with Applications, 36(4), 8218-8226.

Nicola, M., Alsafi, Z., Sohrabi, C., Kerwan, A., Al-Jabir, A., Iosifidis, C., ... Agha, R. (2020). The socio-economic implications of the coronavirus pandemic (COVID-19): A review. International Journal of Surgery, 78(January), 185193.

OECD/ERIA. (2018). SME Policy Index: ASEAN 2018: Boosting Competitiveness and Inclusive Growth, OECD Publishing, Paris/Economic Research Institute for ASEAN and East Asia. Jakarta.

Okfalisa, O., Septia, A., Wresni, A., Muhammad, A., Fauzi, S. S. M., \& Saktioto, S. (2018). Integrated analytical hierarchy process and objective matrix in balanced scorecard dashboard model for performance measurement. Telecommunication Comput. Electron. Control, 16 (6), 2703-2711.

Oudah, M., Jabeen, F., \& Dixon, C. (2018). Determinants linked to family business sustainability in the UAE: An AHP approach. Sustain, 10(1).

Özdağoğlu, A. (2007). Comparison of AHP and Fuzzy AHP for the Multi-Criteria Decision-Making Processes with Linguistic Evaluations. İstanbul Ticaret Üniversitesi Fen Bilimleri Dergisi, 6(11), 65-85-85.

Pal, A., Singh, D., \& Dhaliwal, R. K. (2020). Identification and Relevance of E-readiness Assessment Tools for ICT Use in Agriculture. Current Journal of Applied Science and Technology, 39(16), 93-102.

Parida, A., \& Kumar, U. (2006). Maintenance performance measurement (MPM): Issues and challenges. Journal of Quality in Maintenance Engineering, 12(3), 239-251.

Paschou, T., Adrodegari, F., Rapaccini, M., Saccani, N., \& Perona, M. (2018). Towards service 4.0: A new framework and research priorities. Procedia CIRP, 73, 148-154.

Peillon S., Dubruc N., \& Mansour M. (2018). Service and customer orientation of corporate culture in a French manufacturing SME. Procedia CIRP, 73, 91-5.

Power., D. J. (2003). A Brief History of Decision Support Systems, DSSResources.COM, World Wide Web, URL DSSResources.COM/history/dsshistory2.8.html, version 2.8, May 31, 2003. Provider. Applied Mathematical Modelling, 35(10), 5121-5133.

Prakash, V. A., \& Mittra, R. (2003). Characteristic basis function method: A new technique for efficient solution of method of moments matrix equations. Microwave and Optical Technology Letters, 36(2), 95-100.

Rainer, R. K., \& Cegielski, C. G. (2011). Introduction to information systems: Enabling and transforming business, $3^{\text {rd }}$ ed., New Jersey: John Wiley \& Sons.

Randel, A. E., Galvin, B. M., Shore, L. M., Ehrhart, K. H., Chung, B. G., Dean, M. A., \& Kedharnath, U. (2018). Inclusive leadership: Realizing positive outcomes through belongingness and being valued for uniqueness. Human Resource Management Review, 28(2), 190-203.

Rauch, E., P. Dallasega., \& D. T. Matt. (2017). Critical Factors for Introducing Lean Product Development to Small and Medium Sized Enterprises in Italy. Procedia CIRP, 60, 362-367.

Richards J.C., \& Renandya, W.A. (Ed.). (2002). Methodology in Language Teaching: An Anthology of Current Practice. Cambridge: Cambridge University Press.

Rimantho, D., Putra, W. A., \& Hidayah, N. Y. (2018). Determining the key criteria development of renewable energy in Indonesia using a combination ISM and AHP methods. Journal of Sustainability Science and Management, 13(2), 117128.

Rinto, S., Yustiana, D., \& Suriana, AR. M. (2020). Strategic orientation and performance of SMEs in Indonesia: The mediating role of access to finance. Management Science Letters, 10(2020), 1151-1160.

Rizk N. (2004). E-readiness assessment of small and medium enterprises in Egypt: A micro study. Topics in Middle Eastern and North African Economies, electronic journal, 6, Middle East Economic Association and Loyola University Chicago, http://www.luc.edu/orgs/meea/.

Ruikar, R., Anumba, C. J., \& Carrillo, P. M. (2006). VERDICT-an e-readiness assessment application for construction companies. Automation in Construction, 15, 98-110.

Saaty, T. L. (2000). Fundamentals of decision making and priority theory with the analytic hierarchy process. Pittsburg (CA): RWS

Salah, Y. (2003). IT success and evaluation: A general practitioner model (PhD thesis). Research Institute for the Built Environment $(\mathrm{BuHu})$, University of Salford, Greater Manchester.

Saleem, F., \& Al-Malaise, A. S. (2012). Implementation of data mining approach for building automated decision support systems. Int. Conf. Inf. Soc. i-Society, 127-130.

Samad, M. E. S., \& Steven, D. (2018). Construction technology adoption cube: An investigation on process, factors, barriers, drivers and decision makers using NVIVO and AHP analysis. Journal Buildings, 8(6), 74.

Samaranayake, P. (2009). Business process integration, automation, and optimization in ERP: Integrated approach using enhanced process models. Business Process Management Journal, 15(4), 504-526. 
Schwab. (2016, September 28). The Global Competitiveness Report 2016-2017. Retrieved from https://www.weforum.org/reports/the-global-competitiveness-report-2016-2017-1.

Scupola, A. (2009) SMEs E-commerce Adoption: Perspectives from Denmark and Australia. Journal of Enterprise Information Management, 22(1), 152-166.

Shaverdi, M., Heshmati, M. R., \& Ramezani, I. (2014). Application of fuzzy AHP approach for financial performance evaluation of iranian petrochemical sector. Procedia Computer Science, 31(Itqm), 995-1004.

Siluk, J. C., Kipper, M. L., Bernites, M., \& Nara, E. O. (2016). A performance measurement decision support system method applied for technology-based firm's suppliers. Journal of Decision Systems, 26(1), 93-109.

Sophie, P., \& Nadine, D. (2019). Barriers to digital servitization in French manufacturing SMEs. Procedia CIRP, 83(2019), 146-150.

Stemler \& Steve. (2001). An overview of content analysis. Practical Assessment, Research \& Evaluation. Retrieved from https://scholarworks.umass.edu/pare/vol7/iss1/17.

Straatmann, T., Kohnke, O., Hattrup, K., \& Mueller, K. (2016). Assessing employees' reactions to organizational change: An integrative framework of change-specific and psychological factors. The Journal of Applied Behavioral Science, 52(3), 265-295.

Suhendi, C., Nugroho, M., Yahya, H. B., \& Zahari, A. S. M. (2020). Dynamic capabilities for SME's: Ready to change and cloud service role toward digital business, Proceeding in 17th International Symposium on Management (INSYMA 2020), Atlantis Press, 129-133.

Süße T., Wilkens U., Hohagen S., \& Artinger F. (2018). Digital competence of stakeholders in Product-Service Systems (PSS): Conceptualization and empirical exploration. Procedia CIRP, 73, 197-202.

Syafrida, H., Krisnawati., \& Masta, S. (2018). Enterpreneur's understanding on MSME (Micro Small Medium Enterprises) on concept of sharia financial statements. IOSR Journal of Humanities and Social Cience (IOSR-JHSS), 23(7), 59-65.

Syamala, D. B. \& Srinivasa, R. D. (2017). A Conceptual Model of Sociocultural Determinants of Entrepreneurship. The IUP Journal of Entrepreneurship Development, 13(4), 29-43.

Tak, P. \& Panwar, S. (2017). Using UTAUT 2 model to predict mobile app based shopping: evidences from India. Journal of Indian Business Research, 9(4).

Toni, G., Nikolai, S., \& Christoph, M. F. (2020). Peeking into the void: Digital twins for construction site logistics. Computer in Industry, 121(October), 103264.

Turban, E., Sharda, R., \& Delen, D. (2011). Decision Support and Business Intelligence Systems, Boston: Prentice Hall.

Ulas, D. (2019). Digital Transformation Process and SMEs. Procedia Computer Science, 158, 662-671.

Umeh, F., Tan, C., Pan, Y. C., \& Khan, H. T. (2020). Developing the digital business readiness assessment framework (DBRAF) for fashion retail SMEs in Lagos, Nigeria. Proceeding in 25th UK Academy for Information Systems International Conference (UKAIS 2020), Oxford, UK. (In Press).

Vankudothu, R. N. (2014). Effectiveness and impact analysis of innovative information and communication technologybased extension models. Ph.D. Dissertation. Indian Agricultural Research Institute, New Delhi.

Wahyuni, D. M. N., Wardana, M. I., Yasa, K. N. N., \& Sukaatmadja, G. P. (2020). The effect of culture dimension in digitalization era on the complaint behavior in hotel industry. International Journal of Data and Network Science, 4(4), 347-356.

Walsh, M. F., \& J. Lipinski. (2009). The role of the marketing function in small and medium sized enterprises. J. Small Bus. Enterp. Dev, 16(4), 569-585.

Weeks, W.A., Roberts, J., Chonko, L.B., \& Jones, E. (2004). Organizational readiness for change, individual fear of change, and sales manager performance: An empirical investigation. Journal of Personal Selling \& Sales Management, 24, 718.

Wickham, M. D., \& Woods, M. (2005). Reflecting on the Strategic Use of CAQDAS to Manage and Report on the Qualitative Research Process. The Qualitative Report, 10, 687-702.

Williams, C., Schallmo, D., Lang, K., \& Boardman, L. (2019). Digital Maturity Models for Small and Medium-sized Enterprises: A Systematic Literature Review. ISPIM Conference Proceedings, (June), 1-15.

Wong, A., Holmes, S., \& Schaper, M. T. (2018). How do small business owners actually make their financial decisions? Understanding SME financial behaviour using a case-based approach. Small Enterprise Research, 25(1), 36-51.

Yazdi, M., Orhan, K., \& Sahand, D. (2018). Application of fuzzy fault tree analysis based on modified fuzzy AHP and fuzzy TOPSIS for fire and explosion in process industry. International Journal of Occupational Safety and Ergonomics. 26(2), 319-335.

Zavadskas, E. K., Turskis, Z., Stević, Ž., \& Mardani, A. (2020). Modelling procedure for the selection of steel pipes supplier by applying fuzzy AHP method. Operational Research in Engineering Sciences: Theory and Applications, 3(2), $39-53$.

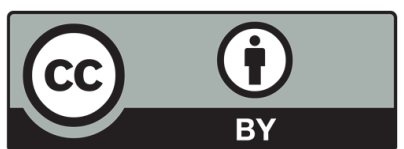

(C) 2021 by the authors; licensee Growing Science, Canada. This is an open access article distributed under the terms and conditions of the Creative Commons Attribution (CC-BY) license (http://creativecommons.org/licenses/by/4.0/). 


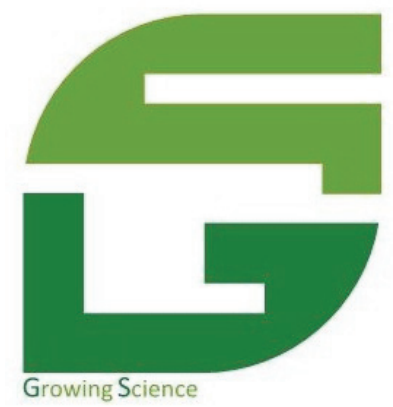

From: Growing Science

200 King street North

N2J 4Z4, Waterloo, Ontario,

Canada, Tel: 519-900-1541

Date: January, 2, 2021

\section{Dear Okfalisa}

I would like to confirm that your paper entitled "Measuring the effects of different factors influencing on the readiness of SMEs towards digitalization: A multiple perspectives design of decision support system" with Wresni Anggraini, Gusman Nawanir, Saktioto and Kuan Yew Wong has been accepted for publication on Decision Science Letters, An international journal indexed by Scopus and Scimago.

We also confirm the receipt of $\$ 715$ for the processing of the paper.

Sincerely,

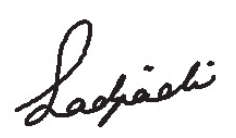

Seyed Jafar Sadjadi

Growing Science 